Article

\title{
Comparative Analysis of Glycoprotein B (gB) of Equine Herpesvirus Type 1 and Type 4 (EHV-1 and EHV-4) in Cellular Tropism and Cell-to-Cell Transmission
}

\section{Bart Spiesschaert ${ }^{1}$, Nikolaus Osterrieder ${ }^{1}$ and Walid Azab ${ }^{1,2, *}$}

1 Institut für Virologie, Robert von Ostertag-Haus, Zentrum für Infektionsmedizin, Freie Universität Berlin, Robert-von-Ostertag-Str. 7-13, Berlin 14163, Germany; E-Mails: bart.spiesschaert@fu-berlin.de (B.S.); no.34@fu-berlin.de (N.O.)

2 Department of Virology, Faculty of Veterinary Medicine, Zagazig University, Zagazig 44519, Egypt

* Author to whom correspondence should be addressed; E-Mail: wfazab@zedat.fu-berlin.de; Tel.: +49-30-8385-1818; Fax: +49-30-8384-51847.

Academic Editor: Marc Johnson

Received: 3 December 2014 / Accepted: 27 January 2015 / Published: 3 February 2015

\begin{abstract}
Glycoprotein B (gB) plays an important role in alphaherpesvirus cellular entry and acts in concert with $\mathrm{gD}$ and the $\mathrm{gH} / \mathrm{gL}$ complex. To evaluate whether functional differences exist between $\mathrm{gB} 1$ and $\mathrm{gB} 4$, the corresponding genes were exchanged between the two viruses. The gB4-containing-EHV-1 (EHV-1_gB4) recombinant virus was analyzed for growth in culture, cell tropism, and cell entry rivaling no significant differences when compared to parental virus. We also disrupted a potential integrin-binding motif, which did not affect the function of $\mathrm{gB}$ in culture. In contrast, a significant reduction of plaque sizes and growth kinetics of gB1-containing-EHV-4 (EHV-4_gB1) was evident when compared to parental EHV-4 and revertant viruses. The reduction in virus growth may be attributable to the loss of functional interaction between $\mathrm{gB}$ and the other envelope proteins involved in virus entry, including $\mathrm{gD}$ and $\mathrm{gH} / \mathrm{gL}$. Alternatively, gB4 might have an additional function, required for EHV-4 replication, which is not fulfilled by gB1. In conclusion, our results show that the exchange of $\mathrm{gB}$ between EHV-1 and EHV-4 is possible, but results in a significant attenuation of virus growth in the case of EHV -4 _gB1. The generation of stable recombinant viruses is a valuable tool to address viral entry in a comparative fashion and investigate this aspect of virus replication further.
\end{abstract}


Keywords: EHV-1; glycoprotein B; tropism; equine

\section{Introduction}

Glycoprotein B $(\mathrm{gB})$ is a type 1 transmembrane protein and represents a highly conserved class III fusion protein present in members of the Herpesviridae family [1]. In members of the Alphaherpesvirinae, it is thought that $\mathrm{gB}$ mediates the virus entry process through membrane fusion after initial attachment of the virion via $\mathrm{gC}$ to cell surface glycosaminoglycans, binding of $\mathrm{gD}$ to its cognate receptor and activation of the heterodimeric gH-gL complex, which in turn primes $\mathrm{gB}$ for fusion [2-9]. In Herpes simplex virus type 1 (HSV-1), gB has been shown to bind several cellular receptors to facilitate viral entry; however, there is no data available on the role of equine herpesvirus type $1(\mathrm{EHV}-1) \mathrm{gB}$ in receptor binding [1]. HSV-1 gB can bind to the paired immunoglobulin-like type 2 receptor (PILR $\alpha$ ) to trigger viral fusion in the presence of $\mathrm{gD}$ [10]. In addition to PILR $\alpha$, non-muscle myosin heavy chain IIA (NMMHCIIA; also known as myosin 9) [11] and myelin-associated glycoprotein (MAG) [12], a protein expressed in neuronal tissues, were also shown to interact with gB and facilitate HSV-1 entry although it has remained unclear whether specific gB-receptor interactions are critical for entry.

Crystal structures of HSV-1 [13] and Epstein-Barr virus (EBV) [14] demonstrated that gB has structural similarity with other viral fusion proteins, such as the $G$ protein of vesicular stomatitis virus (VSV) [15] and gp64 of baculovirus [16], and likely acts as the key herpesviral fusion protein that requires $\mathrm{gH} / \mathrm{gL}$ as a fusion regulator [17-20]. However, it is not fully understood how $\mathrm{gB}$ and $\mathrm{gH} / \mathrm{gL}$ interact during viral fusion.

EHV-1 gB was first described in 1985 as antigenically and structurally similar to HSV-1 gB [21]. Later, it was shown that, like $\mathrm{gB}$ of other alphaherpesviruses, EHV-1 gB is essential for viral growth and direct cell-to-cell spread. This was deduced from the fact that only single infected cells, but no viral plaques, were observed when EHV $-1 \Delta \mathrm{gB}$ was used to infect non-complementing cell lines. A strong indication for its role as a fusogen was also reported; when viral titers of a gB-deficient EHV-1 virus could partly be restored by adding polyethylene glycol to induce fusion [3]. However, there is no data available on the function of EHV-4 gB, the close relative of EHV-1.

EHV-4 (145 kbp) and EHV-1 (150 kbp) both contain 76 unique and highly similar genes. Nucleic acid identity between EHV-4 and EHV-1 genes in general is above $80 \%$, indicating that they are functionally closely related [22-24]. However, despite this high genetic similarity, the disease outcomes after infection differ substantially. EHV-4 only induces mild symptoms that are usually limited to upper respiratory tract infections associated with fever and general malaise [25,26]. While also causing respiratory disease, EHV-1 induces more severe clinical disease that includes abortion in pregnant mares [27-29] and the so-called EHV-1 myeloencephalopathy (EHM) [30,31]. On the cellular level, numerous differences in viral-cell interaction have been described. For instance, both viruses enter cells trough different pathways. More specifically, EHV-1 enters equine epithelial cells via direct fusion at the plasma membrane, while EHV-4 does so via an endocytic pathway [32].

The close genetic relatedness allowed us to exchange essential genes between EHV-1 and EHV-4 and to evaluate the effects both in vitro and in vivo in a way not possible for other members of the subfamily since EHV-1 and EHV-4 naturally infect the same host. We have been interested in exchanging 
glycoproteins that are part of the cell entry complex between EHV-1 and EHV-4 to further elucidate the process of virus entry [32-35]. So far, $\mathrm{gD}$ was found to play an essential role in determining the cellular tropism of EHV-1 and EHV-4 in culture [33]. $\mathrm{gH}$ on the other hand was shown to be responsible for differences in the entry route taken by EHV-1 and EHV-4 [32]. We were interested in exchanging gB to uncover possible functional differences between the two viruses, thereby further elucidating the role of $\mathrm{gB}$ in tropism and pathogenicity. $\mathrm{gB}$ is highly similar between EHV-1 and EHV-4 and the proteins share an amino acid identity of $81.1 \%$ (Figure 1 ).

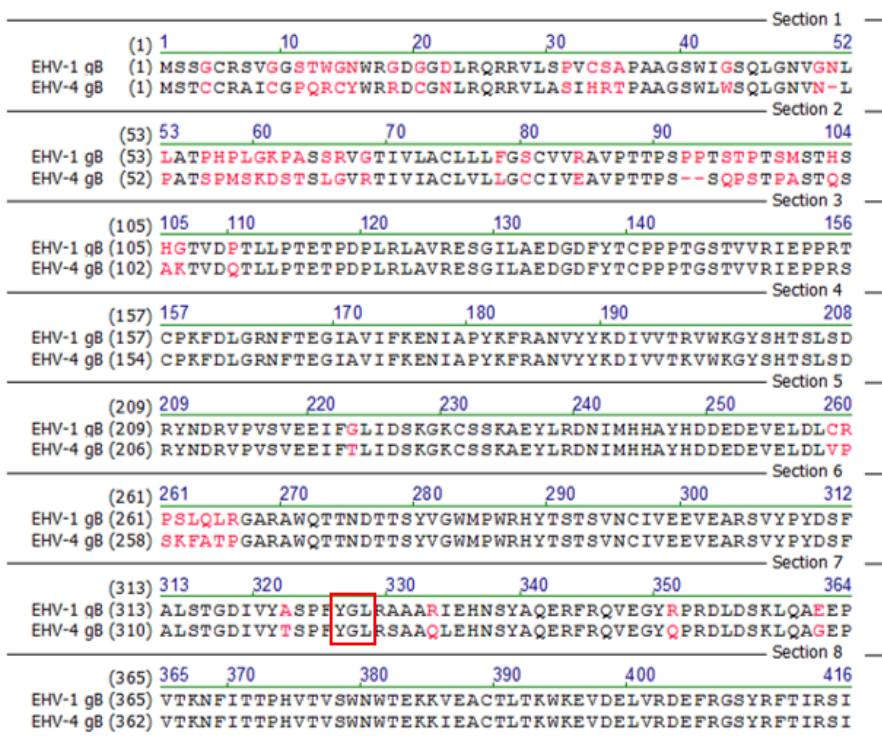

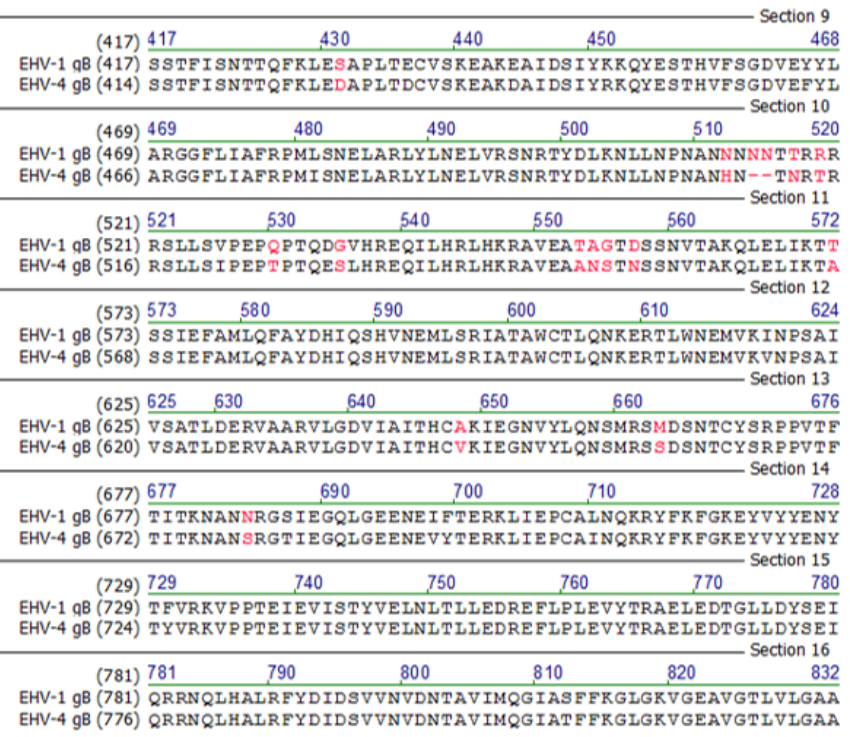

Figure 1. Amino acid sequence alignment of Equine Herpesvirus Type 1 and Type 4 (EHV-1 and EHV-4) glycoprotein B (gB). The putative integrin-binding motif tyrosine-glycine-leucine (YGL) present in the extracellular domains of both gB1 and gB4 (red frame). gB1 and gB4 exhibit 81.1\% sequence identity. Sequences were aligned using Vector NTI software (version 9, Invitrogen, Carlsbad, CA, USA, 2004).

$\mathrm{gB}$ also contains a putative integrin-binding motif, tyrosine-glycine-leucine (YGL), which is conserved in both EHV-1 and EHV-4, and can potentially interact with $\alpha 4 \beta 7, \alpha 4 \beta 1$, and $\alpha 9 \beta 1$ integrins [36]. YGL is also present in the VP4 spike protein of rotaviruses where it mediates cell entry [36]. In a recent study, a similar integrin binding motif, leucine-aspartic acid-isoleucine (LDI), present in EHV-1 gH and interacting with cellular $\alpha 4 \beta 1$ integrins, has been implicated in determining the entry pathway taken by EHV-1 in equine cells [32]. Since integrin-binding motifs were shown to have significant roles during viral infection, we addressed the role of YGL-motif during EHV-1 and EHV-4 entry.

Here we show that exchanging gB between EHV-1 and EHV-4 resulted in the generation of stable recombinant viruses; however, a significant attenuation in the case of EHV-4_gB1 was evident.

\section{Materials and Methods}

\subsection{Viruses}

EHV-1 strain Ab4 [isolated from a quadriplegic mare [37] was cloned as a bacterial artificial chromosome (BAC) by replacing the nonessential gp2 gene with a mini-F plasmid, containing a 
chloramphenicol resistance gene and the enhanced green fluorescence protein (eGFP) gene, (Ab4 $\Delta \mathrm{gp} 2$ ) [38-40]. The EHV-4 infectious BAC clone was generated by the insertion of a loxP-flanked $\mathrm{BAC}$ vector into the intergenic region between genes 58 and 59 [41]. Viruses were reconstituted after transfecting BAC DNA into human embryonic kidney (293T) cells, as described earlier [41-43]. Supernatant and cells were collected $48 \mathrm{~h}$ post-transfection, and high titer stocks of each virus were produced by passaging the transfection product on equine dermal (ED) cells.

\subsection{Plasmids}

Transfer plasmids encoding either EHV-1 or EHV-4 $g B$ with a kanamycin resistance (KanR) gene were constructed. EHV -1 and EHV $-4 g B$ genes were amplified by PCR using primers P1 and P2 or P3 and P4 (Table 1). The PCR products were digested with the restriction enzymes XhoI and XbaI (New England Biolabs, NEB, Schwalbach, Germany) and inserted into the vector pBluescript II KS+ (pKS), resulting in recombinant plasmids $\mathrm{pKSgB1}$ and $\mathrm{pKSgB} 4$. To construct $\mathrm{pKSgB} 1-\mathrm{KanR}$ and pKSgB4-KanR, the KanR gene was amplified by PCR from plasmid pEPkan-S using primers P5, P6, P7, and P8 (Table 1), digested with the appropriate restriction enzymes, and inserted into pKSgB1 and pKSgB4. Correct amplification and insertion were confirmed by Sanger sequencing (LGC Genomics, Berlin, Germany).

Table 1. Oligonucleotide primers used in this study.

\begin{tabular}{|c|c|c|}
\hline Primer & Product & Sequence \\
\hline $\mathrm{P} 1$ & gB1 & aatctcgagatgtcctctggttgecgttc \\
\hline $\mathrm{P} 2$ & gB1 & aactctagattaaaccattttttcatttt \\
\hline P3 & gB4 & aatctcgagatgtccacttgttgccgtgc \\
\hline $\mathrm{P} 4$ & gB4 & acatctagattaaaccattttttcgettt \\
\hline P5 & KanR 1 & accggatccaccgtcgtacgcatcgaaccaggatgacgacgataagtaggg \\
\hline P6 & KanR 1 & ggtggatceggtaggcggtgggcaggtgtcaaccaattaaccaattctgattag \\
\hline P7 & KanR 4 & actggatccacagttgtacgcattgaaccaggatgacgacgataagtaggg \\
\hline P8 & KanR 4 & tgtggatccagtaggcggcgggcaggtgtcaaccaattaaccaattctgattag \\
\hline P9 & gB1 deletion & agcgctgcgtgagcggcatttacataacctacgaggcgtcacatgtttaataaatattataggatgacgacgataagtaggg \\
\hline $\mathrm{P} 10$ & gB1 deletion & tcacactttgagtacgtgtcataatatttattaaacatgtgacgectcgtaggttatgtacaaccaattaaccaattctgattag \\
\hline P11 & gB4 deletion & agcgctgcgetagcggcatttacataacatacgagacgtcaaatgttaaataaatattttaggatgacgacgataagtaggg \\
\hline P12 & gB4 deletion & tcaacccacaagtacgtgtcaaaatatttatttaacatttgacgtctcgtatgttatgtacaaccaattaaccaattctgattag \\
\hline P13 & gB4 KanR & agcggcgcacagcgctgcgtgagcggcatttacataacctacgaggcgtcatgtccacttgttgccgtgc \\
\hline P14 & gB4 KanR & aaatatgaggtcacactttgagtacgtgtcataatatttattaaacatgtttaaaccattttttcgcttt \\
\hline P15 & gB1 KanR & aacggcgcacagcgctgcgctagcggcatttacataacatacgagacgtcatgtcctctggttgccgttc \\
\hline P16 & gB1 KanR & caaatatgagtcaacccacaagtacgtgtcaaaatatttatttaacatttttaaaccattttttcatttt \\
\hline P17 & $\mathrm{gB}^{\mathrm{Y} 336 \mathrm{~A}}$ & ctgtccaccggtgatattgtgtacgcgtctccgtttGCcggcctgagggetgccgctcgcaggatgacgacgataagtaggg \\
\hline P18 & $\mathrm{gB}^{\mathrm{Y} 336 \mathrm{~A}}$ & gtagctattgtgctctatgcgagcggcagccctcaggccgGCaaacggagacgcgtacaccaaccaattaaccaattctgattag \\
\hline P19 & Sequencing & ctcggttttccactgtggag \\
\hline $\mathrm{P} 20$ & Sequencing & ggtgaatgaggatgaaacct \\
\hline $\mathrm{P} 21$ & Sequencing & cgaccacgccaagcccccaac \\
\hline $\mathrm{P} 22$ & Sequencing & cggectcceccactttacccag \\
\hline
\end{tabular}


Table 1. Cont.

\begin{tabular}{ccc}
\hline Primer & Product & Sequence \\
P23 & Sequencing & atcgaaccacctagaacttg \\
P24 & Sequencing & gtcagctggaactggac \\
P25 & Sequencing & gggcgggagtagcacgtgtt \\
P26 & Sequencing & agcccccaaatgggttgt \\
P27 & Sequencing & ccacggtcatgtcccaagtt \\
P28 & Sequencing & ttctcttcggtttccactg \\
P29 & Sequencing & ttggcaaaaatactaggctt \\
\hline
\end{tabular}

Restriction enzyme sites are given in lower case bold letters; sequences in italics indicate additional bases which are not present in the EHV-1 or -4 sequence; Underlined sequences indicate the template binding region of the primers for PCR amplification with pEPkan-S; Upper case bold letters indicate the nucleotides that were mutated.

\subsection{Cells}

293T, Rabbit kidney (RK13), Henrietta Lacks (HeLa), African green monkey kidney (Vero), Crandell feline kidney (CrFK) and Madin-Darby canine kidney (MDCK) cells were propagated in Dulbecco's modified Eagle's medium (DMEM; Biochrom AG, Berlin, Germany) supplemented with 10\% fetal bovine serum (FBS; Biochrom AG), and 1\% penicillin-streptomycin. ED, Chinese hamster ovary (CHO)-K1, and CHO cells expressing HevA, HevB, and HevC (CHO-A, CHO-B and CHO-C cells, respectively; a kind gift from Dr. Patricia Spear, Northwestern University, Chicago, IL, USA) were grown in Iscove's modified Dulbecco's medium (IMDM; Invitrogen, Paisley, UK) supplemented with $20 \%$ FBS, $1 \%$ nonessential amino acids (Biochrom AG) and 1\% $100 \mathrm{mM}$ sodium pyruvate (Biochrom AG).

For generation of Vero cells, which transiently express EHV-4 $g B$ (Vero/gB4), cells were transfected with the vector pcDNA3 (Invitrogen, Paisley, UK) containing $g B 4$ using Lipofectamine 2000 (Invitrogen, Paisley, UK).

Peripheral blood mononuclear cells (PBMC) were isolated from heparinized blood collected by density gradient centrifugation over Histopaque 1077 (Sigma, St. Louis, MO, USA), following the manufacturer's instructions. After two washing steps, cells were suspended in RPMI 1640 supplemented with $10 \%$ FBS, $0.3 \mathrm{mg} / \mathrm{mL}$ glutamine, non-essential amino acids, and $1 \%$ penicillin-streptomycin.

\subsection{BAC Mutagenesis}

The generated BACs were maintained in Escherichia coli (E. coli) GS1783 (a kind gift from Greg Smith, Northwestern University, Chicago, IL, USA), which harbor the recombination system of phage $\lambda$ under the control of a temperature-sensitive repressor [44]. Deletion of the $g B$ gene (UL27) in EHV-1 and EHV-4 was done by a two-step recombination method (Figure 2) as described before [45]. Briefly, primers P9, P10, P11, and P12 (Table 1) were used to generate homology arms (50 nucleotides) by PCR enabling the substitution of $g B$ by KanR. PCR products were digested with DpnI in order to remove residual template DNA. The fragments were then transformed into GS1783 cells containing the BACs by electroporation. Kanamycin-resistant colonies were purified and screened by PCR and restriction fragment length polymorphism (RFLP) to detect correctly recombinant clones. Positive 
clones were subjected to a second round of Red recombination, excising the KanR gene, to obtain the intermediate constructs $\mathrm{pEHV}-1 \Delta \mathrm{gB}$ and $\mathrm{pEHV}-4 \Delta \mathrm{gB}$.

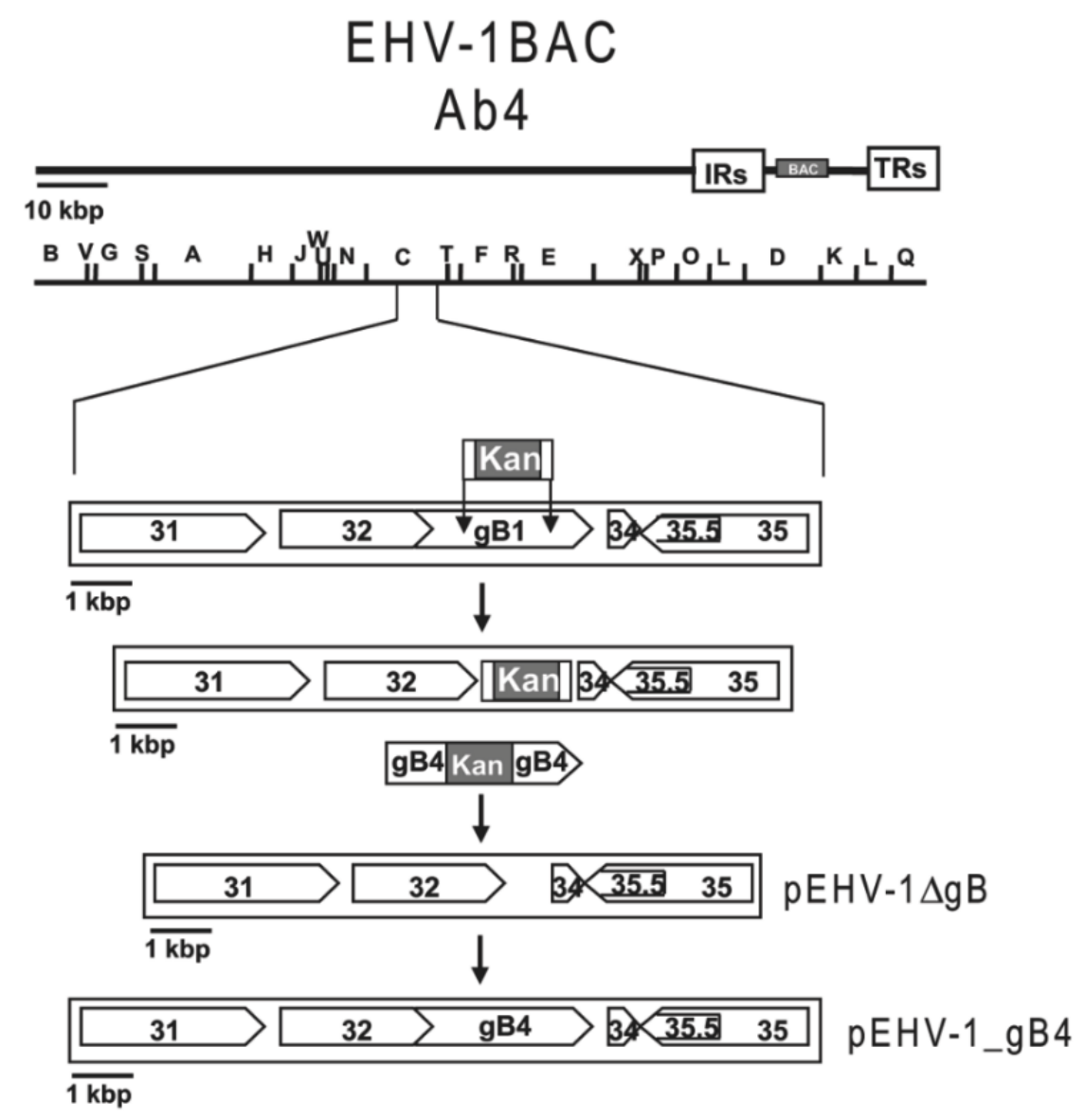

Figure 2. Schematic diagram of the procedures used to construct mutant genomes (EHV-1_gB4 as model). The two unique regions (UL and US) of the EHV-1 genome as well as the terminal and internal repeat sequences (TRS and IRS) are shown, as is the inserted mini-F cassette. PCR products of the kanamycin resistance gene (KanR) were transformed into GS1783 containing the EHV-1 bacterial artificial chromosomes (BACs) by electroporation and the first step of the Red recombination method ensued. In the second step of Red recombination, the KanR gene was excised, thereby obtaining the $\mathrm{pEHV}-1 \Delta \mathrm{gB}$ deletion construct. The PCR-amplified gB4Kan was then electroporated into GS1783 harboring $\mathrm{pEHV}-1 \triangle \mathrm{gB}$, and, again, two-step Red recombination was performed to obtain the final construct pEHV-1_gB4.

The transfer gB1Kan and gB4Kan sequences were amplified by PCR using pKSgB1-KanR and pKSgB4-KanR as templates and primers P13, P14, P15, and P16 (Table 1). PCR products were then electroporated into GS1783 harboring $\mathrm{pEHV}-1 \Delta \mathrm{gB}$ or $\mathrm{pEHV}-4 \Delta \mathrm{gB}$. After selection on LB agar plates containing $34 \mu \mathrm{g} / \mathrm{mL}$ chloramphenicol and $50 \mu \mathrm{g} / \mathrm{mL}$ kanamycin, resistant colonies were purified and screened by PCR and RFLP to detect E. coli harboring recombinant pEHV-1_gB4Kan and pEHV-4_gB1Kan. Positive clones were subjected to a second round of Red recombination to obtain the final constructs pEHV-1_gB4 and pEHV-4_gB1. 
A point mutation targeting the YGL motif present in EHV-1 $\mathrm{gB}$ was generated by introducing alanine into the tyrosine position $\left(\mathrm{EHV}-1 \_\mathrm{gB}^{\mathrm{Y3} 36 \mathrm{~A}}\right)$. Mutants were generated through two-step red recombination using primers $\mathrm{P} 17$ and $\mathrm{P} 18$ (Table 1) as described above.

The respective genotypes of all the mutants and revertants were confirmed by PCR, RFLP, and Sanger sequencing (primers P19-P29; Table 1; data not shown).

\subsection{Western Blot Analysis}

For Western blot analyses, pellets of infected ED cells were suspended in radioimmunoprecipitation assay (RIPA) buffer (50 mM Tris ( $\mathrm{pH} 7.4$ ), 1\% Triton X-100, 0.25\% Na-deoxycholate, $150 \mathrm{mM}$ sodium chloride, $1 \mathrm{mM}$ EDTA) with the complete EDTA-free protease inhibitor cocktail (Roche, Basel, Switzerland). Sample buffer (1 M Tris- $\mathrm{HCl}$ (pH 6.8), 0.8\% sodium dodecyl sulfate (SDS), 0.4\% glycerol, $0.15 \% \beta$-mercaptoethanol, $0.004 \%$ bromophenol blue) was added to lysates, the mixture was heated at $95{ }^{\circ} \mathrm{C}$ for $5 \mathrm{~min}$, and proteins were separated by $10 \%$ SDS-polyacrylamide gel electrophoresis (PAGE) as described before [46]. Expression of gB was detected with anti-EHV-1 gB MAb 3F6, which is also cross-reactive with EHV-4 gB (1:1000) [47]. Rabbit anti- $\beta$-actin antibody (1:2000) (Cell signaling Technologies, Danvers, MA, USA) was included as a loading control. Goat anti-mouse or goat anti-rabbit $(1: 10,000)$ IgG peroxidase conjugates (Southern Biotech, Birmingham, AL, USA) were used as secondary antibodies. Reactive bands were visualized by enhanced chemiluminescence (ECL Plus; Amersham, GE Healthcare, Piscataway, NJ).

\subsection{Virus Growth Assays}

To determine differences in viral replication in culture, single step growth kinetics for EHV-1 and multi-step growth kinetics for EHV-4 were conducted as described before [34]. Briefly, confluent ED cells were infected with a multiplicity of infection (MOI) of 1 in case of EHV-1 parental virus, EHV-1_gB4 and EHV-1 revertant. An MOI of 0.1 was used for EHV-1_ gB ${ }^{\mathrm{Y3} 36 \mathrm{~A}}$ in comparisons with parental EHV-1. In case of parental EHV-4, EHV-4_gB1, and revertant EHV-4, an MOI of 0.01 was used. After $1 \mathrm{~h}$, cells were washed and treated with citrate buffer $(\mathrm{pH}=3)$. Infected cells and supernatant were collected separately for EHV-1 and combined for EHV-4 at the indicated times post infection (p.i.), and stored at $-80^{\circ} \mathrm{C}$. Viral titers were determined on ED cells.

Plaque size measurements were conducted by infecting ED cells for $1 \mathrm{~h}$ at $37{ }^{\circ} \mathrm{C}$ with an MOI of 0.01 , followed by removal of the virus suspension and overlay with DMEM containing $0.5 \%$ methylcellulose (Sigma). After 72 h.p.i, the diameters of 100 fluorescent plaques for each virus were measured using ImageJ software vl.32j (National Institutes of Health, Bethesda, MD, USA, 2004) (http://rsb.info.nih.gov/ij/). The obtained values were normalized and compared to the values of parental viruses, which were set to $100 \%$. Three independent experiments were used to calculate average plaque sizes and standard deviations.

\subsection{Virus Infection Assay}

For evaluating efficiency of replication and cell tropism, confluent monolayers of different cell types were infected with an MOI of 0.1 of the respective viruses. Cells were then washed and overlaid with 
the appropriate medium. After $48 \mathrm{~h}$ p.i, cells were inspected with immunofluorescence microscope (Zeiss Axiovert, Jena, Germany) and pictures were taken with an Axiocam CCD camera (Zeiss, Jena, Germany).

\subsection{Flow Cytometry}

One million PBMC were incubated with EHV-1 and the engineered recombinant viruses at an MOI of 1 for $48 \mathrm{~h}$ at $37^{\circ} \mathrm{C}$. After incubation, the percentage of infected cells was determined by measuring eGFP expression with a FACSCalibur flow cytometer (BD Biosciences, San Jose, CA, USA).

\subsection{Pharmacological Inhibitors}

Cells were pretreated with different drugs for $60 \mathrm{~min}$ as described before [32], and infected with parental and recombinant viruses using an MOI of 0.05 for $24 \mathrm{~h}$ in the presence of the drugs. Cells were then trypsinized and washed twice with PBS. After centrifugation, cells were resuspended in PBS, and 10,000 cells were analyzed for eGFP expression with a FACSCalibur flow cytometer. The drug concentrations used were $100 \mu \mathrm{g} / \mathrm{mL}$ genistein (Sigma) dissolved in DMSO, $10 \mu \mathrm{g} / \mathrm{mL}$ chlorpromazine (Sigma) in PBS, and $80 \mu \mathrm{M}$ dynasore (Sigma) in DMSO.

\subsection{Statistical Analysis}

Statistical analyses (described in context) were performed using GraphPad PRISM (Version 5, GraphPad Software Inc., La Jolla, CA, USA, 2007). Normally distributed datasets, determined with the Shapiro-Wilks test, were analyzed with one-way ANOVA. Datasets that were not normally distributed were analyzed with Kruskal-Wallis one-way analysis of variance for two or more samples that are independent or the Friedman test for repeated measures.

\section{Results}

\section{1. gB Expression by the Recombinant Viruses}

To determine whether gB was properly expressed by the recombinant viruses, ED cells were infected with parental, recombinant and revertant viruses. Cell lysates were then collected and subjected to Western blot analysis. For parental EHV-1, EHV-4 and related recombinant viruses, proteins with molecular weights of approximately 138 and $76 \mathrm{kD}$ were detected that were not present in mock-infected cells (Figure 3). This is in accordance with previous reports where a partially glycosylated precursor of approximately $138 \mathrm{kD}$ and a fully glycosylated subunit of $\mathrm{gB}$ of $75-77 \mathrm{kD}$ were reported to be specifically recognized by MAb 3F6 [48]. These experiments confirmed that all generated recombinant and revertant viruses expressed $\mathrm{gB}$ as expected. 


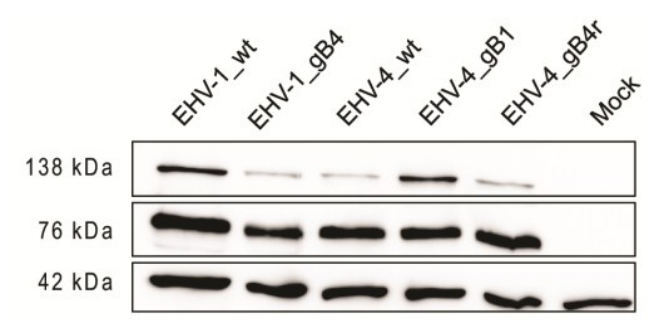

Figure 3. Expression of gB in virus-infected cells. Cell lysates were prepared from infected equine dermal (ED) cells and proteins were separated under reducing conditions by sodium dodecyl sulfate (SDS)-10\%-polyacrylamide gel electrophoresis (PAGE). The blots were incubated with anti-gB monoclonal antibody (MAb)-3F6 and bound antibody detected with anti-mouse IgG peroxidase conjugate. EHV-1, EHV-4 and related recombinant virus proteins with an apparent molecular weight of approximately 130 and $76 \mathrm{kD}$ were detected that are not present in mock-infected cells. Rabbit anti- $\beta$-actin antibody was used as a loading control (molecular weight of approximately $42 \mathrm{kDa}$ ).

\subsection{EHV-4 gB Is Essential for Viral Replication}

pEHV-4 $\triangle \mathrm{gB}$ DNA was transfected into Vero cells and the cells were monitored for $48 \mathrm{~h}$. Only single infected cells (eGFP-positive/fluorescent cells) could be detected of which the number did not increase over time (Figure 4a). In contrast, Vero cells transfected with parental EHV-4 DNA showed syncytium formation after $48 \mathrm{~h}$ (Figure 4c). When Vero cells, which were transfected with gB4 as described

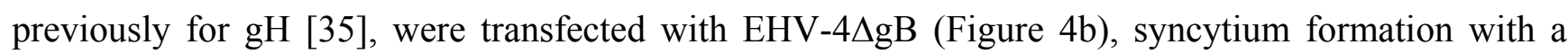
morphology similar to that induced by parental EHV-4 (Figure 4d) could be seen.
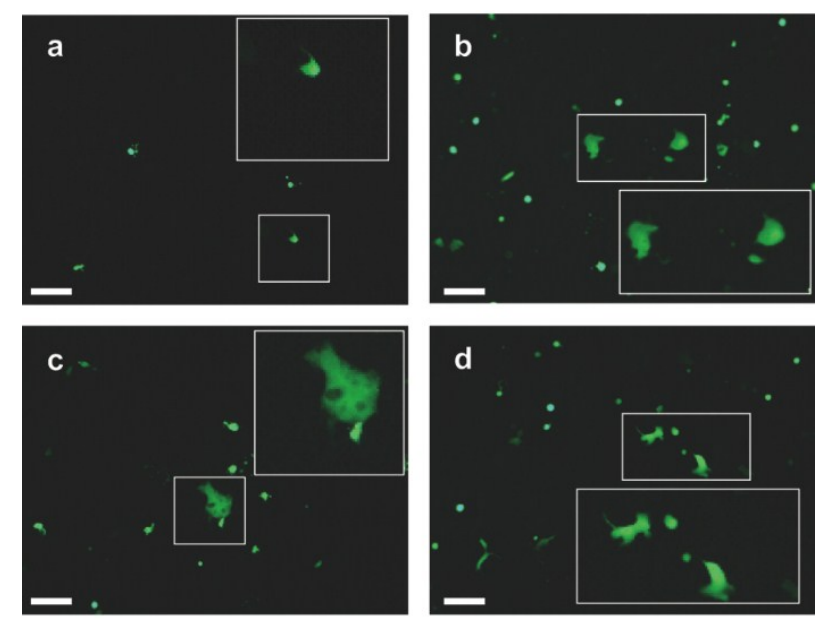

Figure 4. Transfection of African green monkey kidney (Vero) cells with EHV-4 $\Delta \mathrm{gB}$. EHV-4 $\triangle \mathrm{gB}$ DNA was transfected in Vero cells (a) and Vero/gB4 cells (b). Also, parental EHV-4 DNA was transfected in both Vero (c) and Vero/gB4 cells (d). After $48 \mathrm{~h}$ of incubation, cells were inspected with an epifluorescent microscope (Zeiss Axiovert, Jena, Germany) and images were taken with a CCD camera (Zeiss Axiocam, Jena, Germany). The bar represents $100 \mu \mathrm{m}$ and the white frames contain magnified inserts of the selected areas. Plaque formation of the gB-negative EHV-4 mutant was only evident on Vero/gB4 but not parental Vero cells. 


\subsection{Virus Growth in Culture}

No significant differences were observed for any of the EHV-1 recombinants when compared to the parental virus (Figure 5a,c,d). We therefore concluded that the growth properties of recombinant EHV-1 in culture were not significantly affected by the exchange with EHV-4 gB.

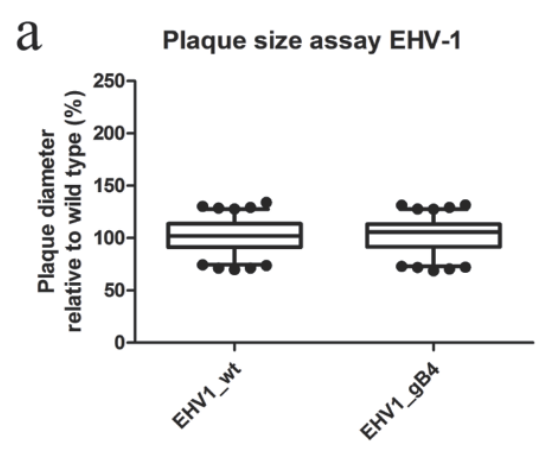

c

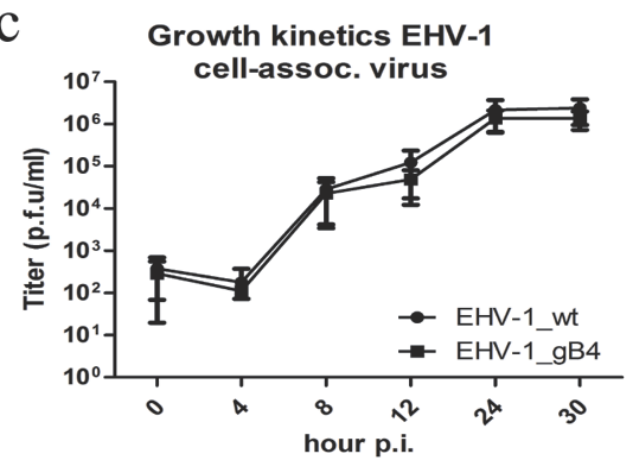

e

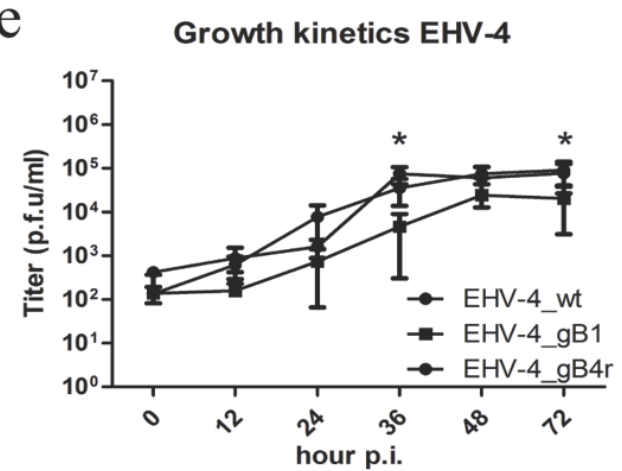

b

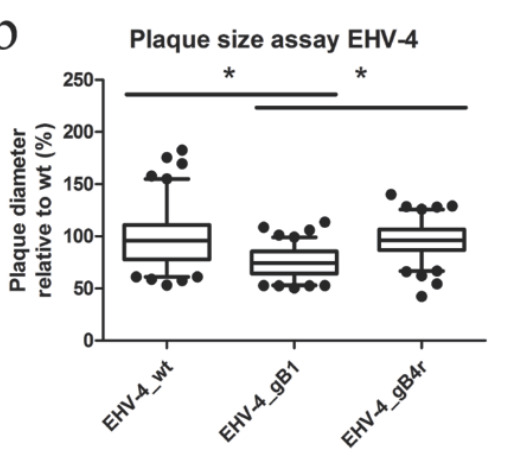

d

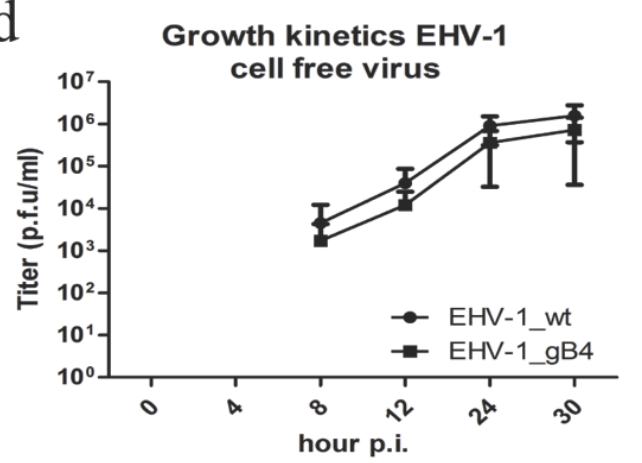

Figure 5. Growth characteristics of parental and recombinant EHV-1 and EHV-4 in cell culture. ED cells were infected with the respective viruses at a multiplicity of infection (MOI) of 0.01 . Means \pm SD of diameters of 100 plaques measured for each virus are shown. The plaque diameter of parental viruses was set to $100 \%$. No significant differences (one-way ANOVA; $p>0.05$ ) between parental EHV-1 and EHV-1_gB4 were obvious (a). A significant reduction (one-way ANOVA; $p<0.05$ ) of plaque size for EHV-4_gB1 was evident when compared to parental and revertant virus. Means \pm SD of diameters of 100 plaques measured for each virus are shown. The plaque diameter of parental viruses was set to $100 \%$ (b). For single step growth kinetics of EHV-1 recombinant viruses, ED cells were infected at an MOI of $1(\mathbf{c}, \mathbf{d})$, followed by citrate treatment $(\mathrm{pH}=3)$ to remove remaining extra-cellular virions. Infected cells (c) and supernatants (d) were separately collected and 
virus titers were determined at the indicated times post-infection (p.i). The data presented are means \pm SD of three independent measurements. No significant differences were measured for the EHV-1 recombinant viruses when compared to the parental viruses (Friedman test-Dunn's multiple comparison test; $p>0.05$ ). (e) For multi-step growth kinetics of EHV-4_gB1, ED cells were infected at MOI of 0.01 , followed by washing. Infected cells and supernatants were collected and virus titers were determined at the indicated times p.i. The data presented are means \pm SD of three independent measurements. A significant decrease was measured for EHV-4_gB1 at several time points $(*)$ when compared to the parental and revertant viruses (Friedman test-Dunn's multiple comparison test; $p<0.05$ ).

In the case of EHV-4_gB1, however, significantly reduced plaque sizes were seen compared to parental and revertant viruses (Figure 5b). Similarly, EHV-4_gB1 also showed a significantly reduced growth rate at several time points as evidenced by the growth kinetics (Figure 5e).

\section{4. $\mathrm{gB}$ Has No Role in Determining the Host Range of EHV-1 and EHV-4 in Culture}

EHV-1 can replicate and spread in many cell lines from equine and other origin [49]. In contrast, EHV-4 appears to be restricted mainly to equine cells and replicates poorly in only few cell lines, such as Vero cells [43]. In order to investigate whether gB plays a role in determining host range, as already shown for gD [33], several cell lines that are only permissible for either EHV-1 or EHV-4 were infected. Contrary to the exchange of $\mathrm{gD}$ between the two viruses, no changes in permissiveness were seen after exchanging gB between EHV-1 and EHV-4 (Figure 6; Table 2).

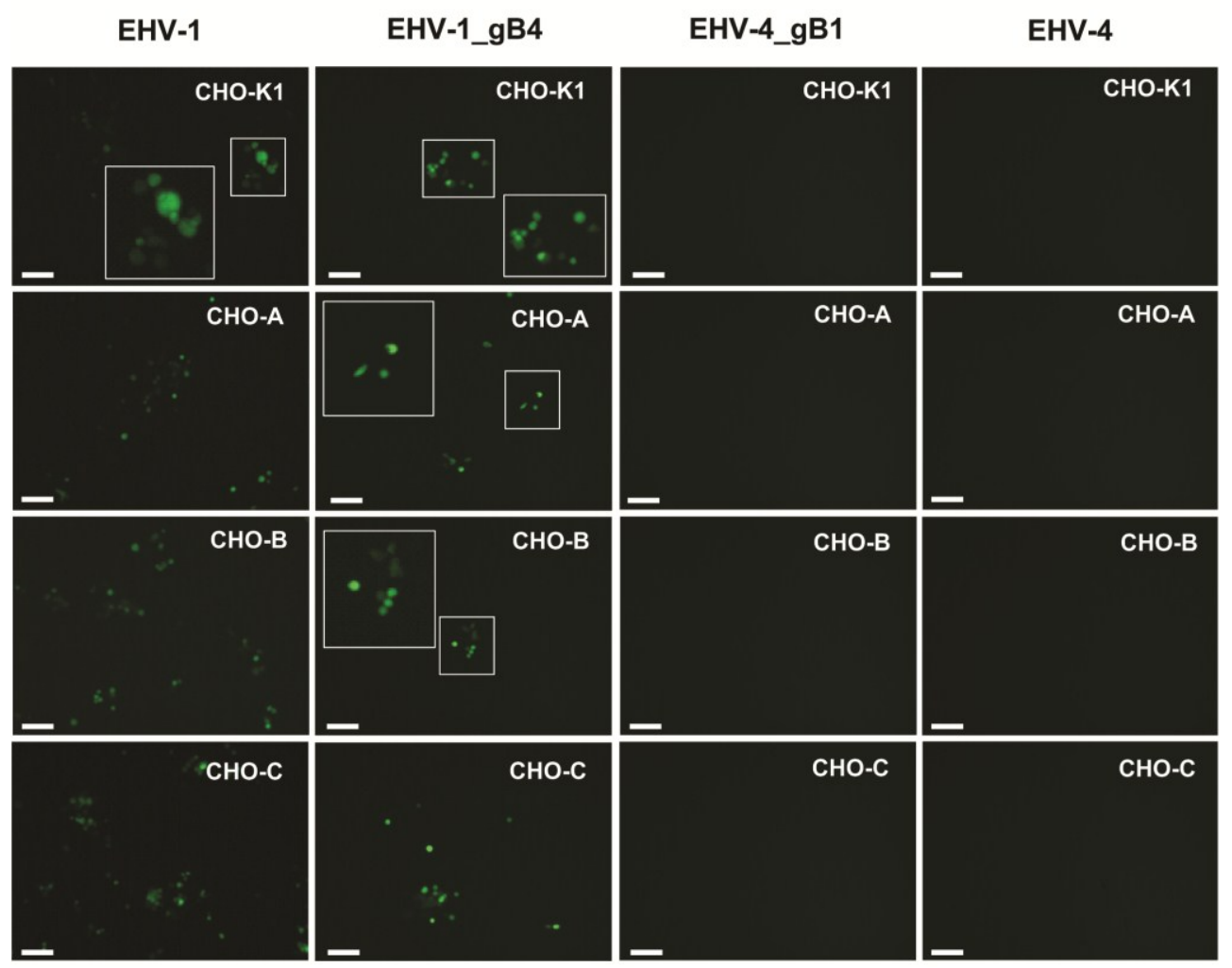

Figure 6. Cont. 


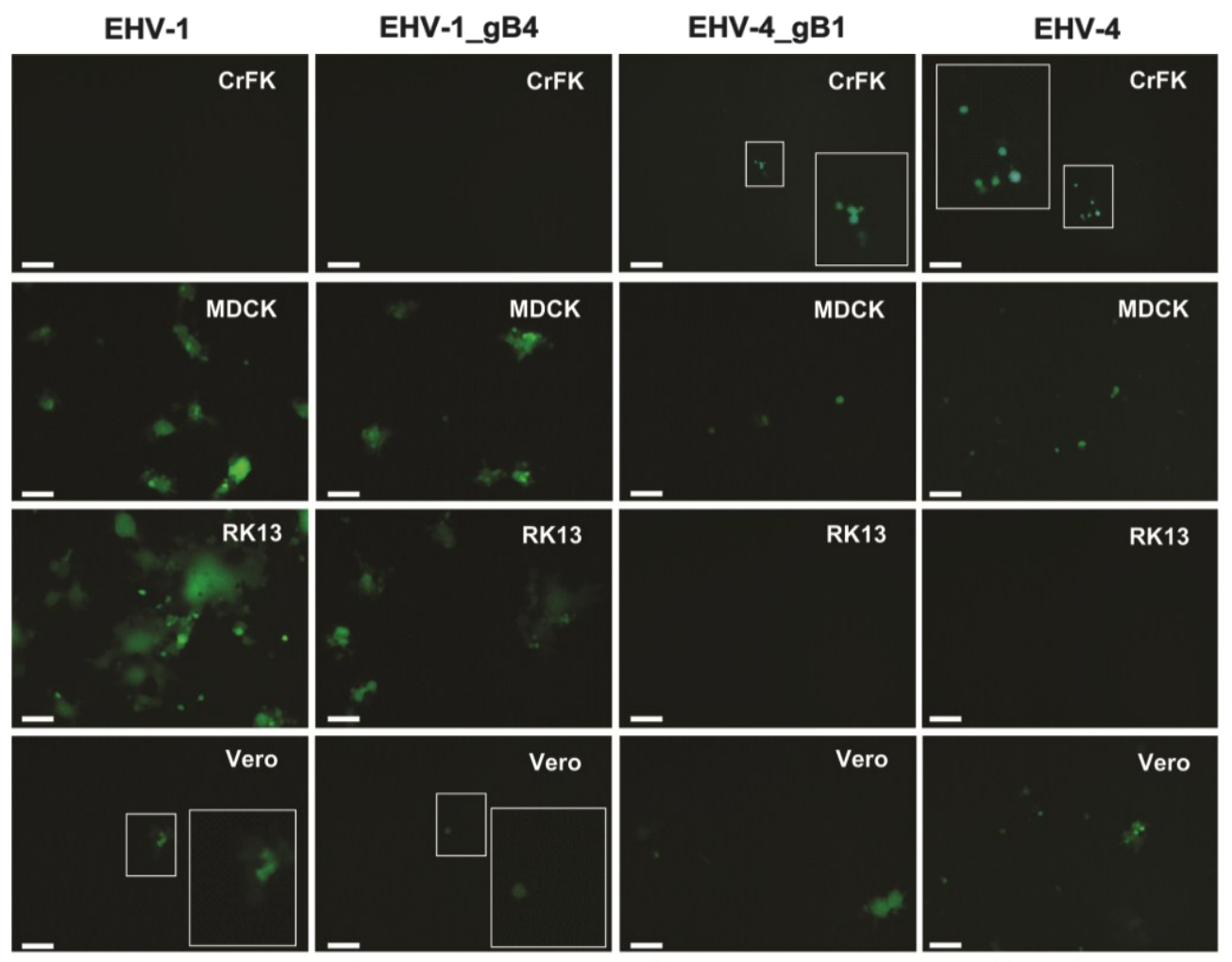

Figure 6. The role of $\mathrm{gB}$ in EHV-1 cellular tropism. Chinese hamster ovary (CHO)-K1, CHO-A, CHO-B, CHO-C, Crandell feline kidney (CrFK), Madin-Darby canine kidney (MDCK), Rabbit kidney (RK13) and Vero cells were infected at an MOI of 0.1 with the parental EHV-1 and EHV-1_gB4, all of which express eGFP. At 24 h p.i., cells were inspected with a fluorescent microscope (Zeiss Axiovert, Jena, Germany) and images were taken with a CCD camera (Zeiss Axiocam, Jena, Germany). The bar represents $100 \mu \mathrm{m}$ and the white frames contain magnified inserts of the selected areas. CHO-K1, CHO-A, CHO-B and $\mathrm{CHO}-\mathrm{C}$, and RK13 cells were highly resistant and MDCK virtually resistant to parental and recombinant EHV-4 infection. In addition, CrFK were highly resistant and Vero cells virtually resistant to parental and recombinant EHV-1 infection.

Table 2. The role of gB in EHV-1 cellular tropism.

\begin{tabular}{ccccc}
\hline Cell line & EHV-1 & EHV-1 gB4 & EHV-4 & EHV-4 gB1 \\
\hline CHO-K1 & + & + & - & - \\
CHO-A & + & + & - & - \\
CHO-B & + & + & - & - \\
CHO-C & + & + & - & - \\
CrFK & - & - & + & + \\
MDCK & + & + & + & + \\
RK13 & + & + & - & - \\
Vero & + & + & + & + \\
\hline
\end{tabular}




\subsection{The Integrin-Binding Motif YGL Is Not Involved in EHV-1 Entry}

The integrin-binding motif YGL was predicted with the I-TASSER server and is present in the extracellular domain of $\mathrm{gB}$ (http://zhang.bioinformatics.ku.edu/I-TASSER/). The motif is conserved in both EHV-1 and EHV-4. The YGL motif was mutated into AGL in EHV-1 (EHV-1_gB $\left.{ }^{\mathrm{Y} 336 \mathrm{~A}}\right)$ to evaluate its importance for cell entry and determining the cell entry pathway.

In previous studies, function-blocking MAbs $\alpha 4 \beta 1$ and $\alpha 4 \beta 7$ were used to investigate the role of integrins during entry into PBMC, ED and fetal horse kidney (FHK) cells. It was shown that blocking these potential receptors for EHV-1 and EHV-4 had no effect on their growth in culture or their ability to infect PBMC [35]. However, this does not exclude the possibility that the YGL motif could have an effect on viral growth and infection rates, since other unknown binding partners could be involved. However, no changes could be seen for either viral growth in culture (Figure 7a,c,d) or infection rates in PBMC (Figure 7b) between parental EHV-1 and EHV-1_gB ${ }^{\mathrm{Y} 336 \mathrm{~A}}$.
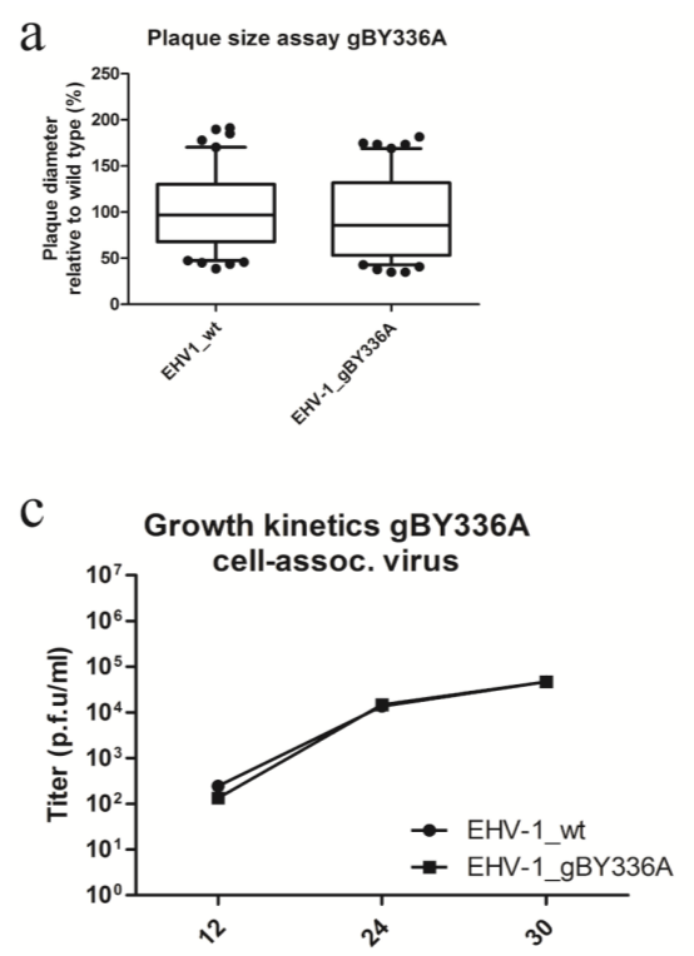

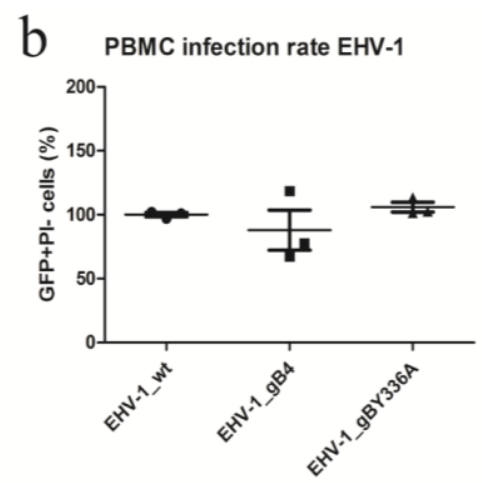

d

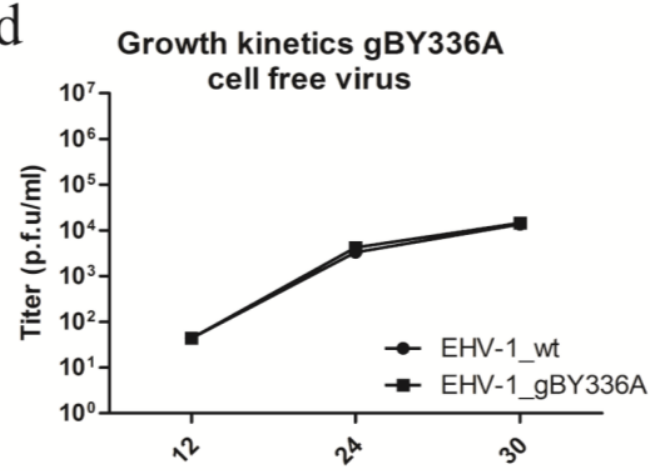

Figure 7. Characterization of EHV-1_gBY336A. (a) ED cells were infected with the respective viruses at an MOI of 0.01 . Means \pm SD of diameters of 100 plaques measured for each virus are shown. The plaque diameter of parental viruses was set to $100 \%$. No significant differences (one-way ANOVA; $p>0.05$ ) between parental EHV-1 and EHV-1_gBY336A were evident; (b) One million peripheral blood mononuclear cells (PBMC) were incubated with parental and recombinant EHV-1 viruses at an MOI of 1 for $24 \mathrm{~h}$ at $37{ }^{\circ} \mathrm{C}$. After incubation, the percentage of infected cells was determined by flow cytometry. The rate of infection of parental virus was set to $100 \%$. All data represent the means \pm SD of three independent experiments (Kruskal-Wallis one-way analysis of variance; $p>0.05)$. For single-step growth kinetics of EHV-1 recombinant viruses, ED cells were infected at an MOI of $0.1(\mathbf{c}, \mathbf{d})$, followed by citrate treatment $(\mathrm{pH}=3)$ to remove 
remaining extracellular virions. Infected cells (c) and supernatants (d) were separately collected and virus titers were determined at the indicated times p.i. The data presented are means \pm SD of three independent measurements. No significant differences were detectable for the EHV-1 recombinant viruses when compared to the parental viruses (Friedman test-Dunn's multiple comparison test; $p>0.05$ ).

\section{6. $g B$ and YGL Do Not Play a Role in Determining the Cell Entry Pathway}

To investigate whether $\mathrm{gB}$ or the YGL motif have an effect on the viral entry pathways used by EHV-1, we conducted inhibitor studies using drugs that target various cellular functions associated with viral cell entry as described previously for $\mathrm{gH}$ [32].

Caveolae are plasma membrane invaginations that play an important role in cellular uptake of EHV-4 or EHV-1 after replacing authentic gH1 with EHV-4 gH [32]. Caveolae-mediated uptake depends on dynamin II [50], which can be inhibited by dynasore [51], and tyrosine kinases, which can be inhibited by genistein [52]. Chlorpromazine affects Clathrin-mediated endocytosis through the inhibition of Clathrin adaptor protein 2 assembly [53]. Since this drug does not affect the uptake of EHV-1 and EHV-4 [32], it was used as a negative control.

Contrary to the differences in cell entry pathway seen when exchanging $\mathrm{gH}$, no significant differences could be seen between parental EHV-1 and EHV-1_gB4 or EHV-1_gB ${ }^{\mathrm{Y3} 36 \mathrm{~A}}$ after using different inhibitors. In the case of EHV-4_gB1 as well as parental EHV-4, the number of infected cells was significantly reduced when treated with either genistein or dynasore. These data clearly indicated that $\mathrm{gB}$ has no role in routing the entry pathway of EHV-1 (Figure 8), but is rather required for entry steps after receptor binding.
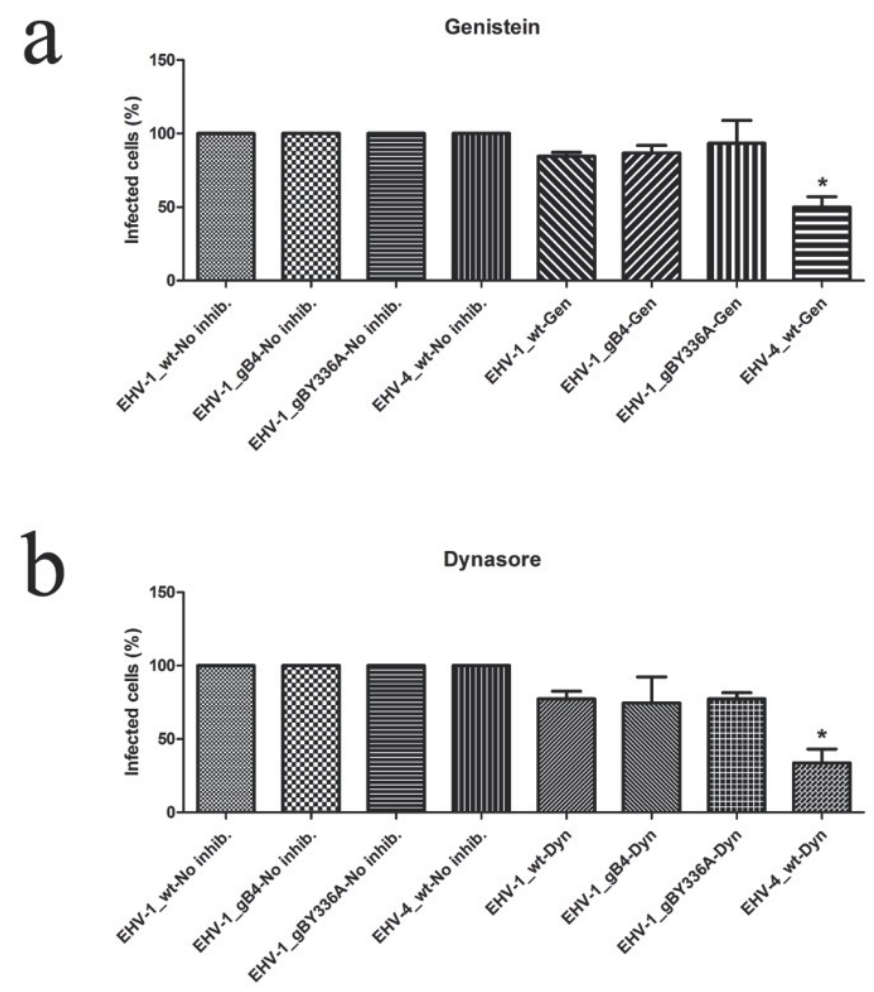

Figure 8. Cont. 


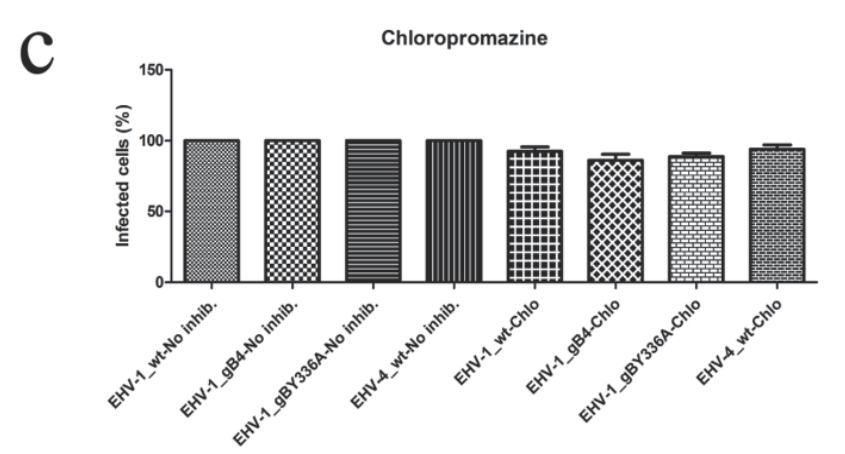

Figure 8. Inhibition of cell entry. Equine dermal (ED) cells were treated with the inhibitors genistein (Gen; a), dynasore (Dyn; b) and chlorpromazine (Chlo; c), as indicated, before infection with parental or recombinant viruses at an MOI of 0.05 . At $24 \mathrm{~h}$ p.i., cells were washed and the percentage of infected cells was determined by flow cytometry. The percentage of infection of the parental virus was set to $100 \%$. The percentage of infection $\left(\mathrm{eGFP}^{+}\right)$in the absence of inhibitors was set to $100 \%$. All data represent the means \pm SD of three independent experiments. Significant decreases $(*)$ were only seen for EHV-4_wt in the presence of dynasore and genestein (Kruskal-Wallis one-way analysis of variance; $p<0.05)$. However, no significant differences in infection rate were seen between parental and recombinant viruses in the different settings (Kruskal-Wallis one-way analysis of variance; $p>0.05)$.

\section{Discussion}

For several alphaherpesviruses, including EHV-1, it has been shown that $\mathrm{gB}$ is essential for infection [7,54-58]. More specifically, gB plays an important role in the cell-to-cell spread of alphaherpesviruses [2-6]. In the present study, we have addressed the importance of gB for EHV-4 replication. We have shown that the number of infected cells after transfection with $\mathrm{pEHV}-4 \Delta \mathrm{gB}$ did not increase over time. This suggests that EHV-4 is not able to either be released from infected cells or enter uninfected cells without the help of $\mathrm{gB}$. The gB-deleted virus was only able to induce syncytium formation when grown in pcDNAgB4-transfected Vero cells, in other words when the glycoprotein was provided in trans. It has been shown that $\mathrm{gB}$ is involved in virus maturation and egress from the infected cells for different herpesviruses including HSV-1 and Kaposi's sarcoma-associated herpesvirus [59,60]. EHV-4 gB may also play a role in viral egress, including first or secondary envelopment or virion release into the extracellular space. However, we view an involvement of EHV-4 gB in egress as unlikely as those of other varicelloviruses are not required in the process either. Rather, we presume an essential role in virus entry and cell-to-cell spread but the exact role and the mechanism are not known at present and need to be further investigated. Taken together, the essentiality of $\mathrm{gB}$ functions during different virus replication steps is not unique to EHV-4 as all of the $\mathrm{gB}$ homologues across all subfamilies of the Herpesviridae studied until now have been shown to play similar roles.

The replacement of gB1 by gB4 in EHV-1 did not lead to significant changes in viral growth in culture. However, the EHV-4_gB1 recombinant exhibited a markedly reduced growth defect as evidenced by impaired viral cell-to-cell spread and reduced growth kinetics. This was particularly surprising since no apparent growth defect was seen in culture during previously conducted experiments 
where $\mathrm{gB}$ were exchanged between alphaherpesviruses of different natural hosts [61]. The growth defect of EHV-4_gB1 could be caused by a structural incompatibility of gB1 that EHV-4 was unable to compensate for. Alternatively, gB4 might have an additional role required for EHV-4 replication but not fulfilled by $\mathrm{gB} 1$. In a previous study, where $\mathrm{gB}$ of $\mathrm{HSV}-1$ was replaced with $\mathrm{gB}$ of Saimiriine Herpesvirus 1 (SaHV-1), it was shown that HSV-1 gB possessed and additional function lacking for SaHV-1 gB. Loss of functional interaction with PIRL $\alpha$ was reported for SaHV-1 despite sequence alignment suggesting that the interaction site is conserved [62].

Therefore, it would be interesting to further elucidate the structural differences between gB1 and gB4 and identify putative viral interaction partners of $\mathrm{gB}$. After binding of $\mathrm{gD}$ to cellular receptors it activates gH-gL complex, which in turn primes gB for fusion. Perhaps, the authentic EHV-4 gH-gL complex could not prime $\mathrm{gB} 1$ as efficiently as the native $\mathrm{gB} 4$ for fusion. It will, therefore, be interesting to examine whether a triple mutant, i.e., EHV-4 harboring gH1-gL1-gB1 and vice versa, would lead to any changes of the virus' ability to effectively replicate.

Recently it was shown that EHV-1 gD, besides its primary interaction partner MHC class I, can bind to a wide array of receptors and that it is responsible for determining the host range of the virus. The case is less clear for EHV-4 gD, which also uses MHC class I as an entry receptor and likely another molecule to enter, e.g. Vero cells [33]. In the current study, we showed that exchanging gB has no effect on the entry of the recombinant viruses into the selected cell lines, suggesting that $\mathrm{gB}$ is not important in determining cellular host range. It seems likely that, in contrast to HSV-1 [10-12], gB of EHV-1 or EHV-4 does not need to bind to different cellular receptors to facilitate fusion, that $\mathrm{gB}$ binding is not important for cellular tropism, or that $\mathrm{gB}$ and receptor interaction are not absolutely required for entry. However, this conclusion does not exclude the role of $\mathrm{gB}$, together with $\mathrm{gC}$, to bind cell surface heparan sulfate and help the attachment of virions to cells during the initial events of infection [34].

Disrupting the integrin-binding motif YGL in gB1 did not have any effect on virus growth in culture. Furthermore, YGL apparently does not play a decisive role in determining the cell entry pathway of EHV-1 or EHV-4. These results are in accordance with previous work where binding between the integrin-binding motif YGL and selected known ligands $\alpha 4 \beta 1$ or $\alpha 4 \beta 7$ was mitigated using blocking antibodies. These experiments revealed that YGL does not need to interact with its known binding partners for infection [35]. From these results, we concluded that gB-integrin interaction does not play an important role in cell entry or determining the cell entry pathway; however, it may have a role in signaling transduction that might be needed during other steps of virus replication. Furthermore, these data do not necessarily mean that no interaction occurs between EHV-1 and the respective integrins. The integrins may serve as a receptor and/or co-receptor for viral entry and their blockade may not have a measurable effect on virus infection, especially, if alternative receptors exist.

Due to its importance in cell-to-cell spread [6], gB would be an interesting target for future research on the spread of EHV-1 between infected PBMC and endothelial cells (EC). This process enables infection of EC even in the presences of neutralizing antibodies, causing vascular lesions and secondary hypoxic degeneration of affected tissues [24,63].

In summary, the replacement of gB1 by gB4 in EHV-1 did not lead to any significant changes in viral growth in culture compared to EHV-1. However, EHV-4 seems to be unable to fully compensate the structural changes introduced by the replacement of gB4 with gB1 with respect to replication in culture. 
Nonetheless, the generation of a stable EHV-1_gB4 recombinant virus gives us the tools to address viral entry and spread of EHV-1 and EHV-4 in other cell types in the future.

\section{Acknowledgments}

This work was supported by the Elsa-Neumann Grant awarded to Bart Spiesschaert and a grant from Deutsche Forschungsgemeinschaft (DFG; AZ 97/3-1 AO606893) to Walid Azab.

\section{Author Contributions}

Bart Spiesschaert contributed to this work by designing, carrying out all the experiments, analyzing and interpreting the data. Nikolaus Osterrieder contributed to the drafting of the manuscript, revising it critically, and giving final approval of the version to be published. Walid Azab contributed to designing and interpreting the data as well as drafting of the manuscript and revising it critically. All authors read and approved the final manuscript.

\section{Conflicts of Interest}

The authors declare no conflict of interest.

\section{References}

1. Connolly, S.A.; Jackson, J.O.; Jardetzky, T.S.; Longnecker, R. Fusing structure and function: A structural view of the herpesvirus entry machinery. Nat. Rev. Microbiol. 2011, 9, 369-381.

2. Csellner, H.; Walker, C.; Wellington, J.E.; McLure, L.E.; Love, D.N.; Whalley, J.M. EHV-1 glycoprotein D (EHV-1 gD) is required for virus entry and cell-cell fusion, and an EHV-1 gD deletion mutant induces a protective immune response in mice. Arch. Virol. 2000, 145, 2371-2385.

3. Neubauer, A.; Braun, B.; Brandmuller, C.; Kaaden, O.R.; Osterrieder, N. Analysis of the contributions of the equine herpesvirus 1 glycoprotein $\mathrm{gB}$ homolog to virus entry and direct cell-to-cell spread. Virology 1997, 227, 281-294.

4. Osterrieder, N. Construction and characterization of an equine herpesvirus 1 glycoprotein $\mathrm{C}$ negative mutant. Virus Res. 1999, 59, 165-177.

5. Stokes, A.; Alber, D.G.; Greensill, J.; Amellal, B.; Carvalho, R.; Taylor, L.A.; Doel, T.R.; Killington, R.A.; Halliburton, I.W.; Meredith, D.M. The expression of the proteins of equine herpesvirus 1 which share homology with herpes simplex virus 1 glycoproteins $\mathrm{H}$ and L. Virus Res. 1996, 40, 91-107.

6. Wellington, J.E.; Love, D.N.; Whalley, J.M. Evidence for involvement of equine herpesvirus 1 glycoprotein B in cell-cell fusion. Arch. Virol. 1996, 141, 167-175.

7. Cai, W.H.; Gu, B.; Person, S. Role of glycoprotein B of herpes simplex virus type 1 in viral entry and cell fusion. J. Virol. 1988, 62, 2596-2604.

8. Atanasiu, D.; Whitbeck, J.C.; Cairns, T.M.; Reilly, B.; Cohen, G.H.; Eisenberg, R.J. Bimolecular complementation reveals that glycoproteins $\mathrm{gB}$ and $\mathrm{gH} / \mathrm{gL}$ of herpes simplex virus interact with each other during cell fusion. Proc. Natl. Acad. Sci. USA 2007, 104, 18718-18723. 
9. Avitabile, E.; Forghieri, C.; Campadelli-Fiume, G. Complexes between herpes simplex virus glycoproteins $\mathrm{gD}, \mathrm{gB}$, and $\mathrm{gH}$ detected in cells by complementation of split enhanced green fluorescent protein. J. Virol. 2007, 81, 11532-11537.

10. Satoh, T.; Arii, J.; Suenaga, T.; Wang, J.; Kogure, A.; Uehori, J.; Arase, N.; Shiratori, I.; Tanaka, S.; Kawaguchi, Y.; et al. PILRalpha is a herpes simplex virus-1 entry coreceptor that associates with glycoprotein B. Cell 2008, 132, 935-944.

11. Arii, J.; Goto, H.; Suenaga, T.; Oyama, M.; Kozuka-Hata, H.; Imai, T.; Minowa, A.; Akashi, H.; Arase, H.; Kawaoka, Y.; et al. Non-muscle myosin IIA is a functional entry receptor for herpes simplex virus-1. Nature 2010, 467, 859-862.

12. Suenaga, T.; Satoh, T.; Somboonthum, P.; Kawaguchi, Y.; Mori, Y.; Arase, H. Myelin-associated glycoprotein mediates membrane fusion and entry of neurotropic herpesviruses. Proc. Natl. Acad. Sci. USA 2010, 107, 866-871.

13. Heldwein, E.E.; Lou, H.; Bender, F.C.; Cohen, G.H.; Eisenberg, R.J.; Harrison, S.C. Crystal structure of glycoprotein B from herpes simplex virus 1. Science 2006, 313, 217-220.

14. Backovic, M.; Longnecker, R.; Jardetzky, T.S. Structure of a trimeric variant of the Epstein-Barr virus glycoprotein B. Proc. Natl. Acad. Sci. USA 2009, 106, 2880-2885.

15. Roche, S.; Bressanelli, S.; Rey, F.A.; Gaudin, Y. Crystal structure of the low-pH form of the vesicular stomatitis virus glycoprotein G. Science 2006, 313, 187-191.

16. Kadlec, J.; Loureiro, S.; Abrescia, N.G.; Stuart, D.I.; Jones, I.M. The postfusion structure of baculovirus gp64 supports a unified view of viral fusion machines. Nat. Struct. Mol. Biol. 2008, 15, 1024-1030.

17. Atanasiu, D.; Whitbeck, J.C.; de Leon, M.P.; Lou, H.; Hannah, B.P.; Cohen, G.H.; Eisenberg, R.J. Bimolecular complementation defines functional regions of Herpes simplex virus $\mathrm{gB}$ that are involved with $\mathrm{gH} / \mathrm{gL}$ as a necessary step leading to cell fusion. J. Virol. 2010, 84, 3825-3834.

18. Backovic, M.; DuBois, R.M.; Cockburn, J.J.; Sharff, A.J.; Vaney, M.C.; Granzow, H.; Klupp, B.G.; Bricogne, G.; Mettenleiter, T.C.; Rey, F.A. Structure of a core fragment of glycoprotein H from pseudorabies virus in complex with antibody. Proc. Natl. Acad. Sci. USA 2010, 107, 22635-22640.

19. Chowdary, T.K.; Cairns, T.M.; Atanasiu, D.; Cohen, G.H.; Eisenberg, R.J.; Heldwein, E.E. Crystal structure of the conserved herpesvirus fusion regulator complex gH-gL. Nat. Struct. Mol. Biol. 2010, 17, 882-888.

20. Matsuura, H.; Kirschner, A.N.; Longnecker, R.; Jardetzky, T.S. Crystal structure of the Epstein-Barr virus (EBV) glycoprotein H/glycoprotein L (gH/gL) complex. Proc. Natl. Acad. Sci. USA 2010, 107, 22641-22646.

21. Snowden, B.W.; Kinchington, P.R.; Powell, K.L.; Halliburton, I.W. Antigenic and biochemical analysis of $\mathrm{gB}$ of herpes simplex virus type 1 and type 2 and of cross-reacting glycoproteins induced by bovine mammillitis virus and equine herpesvirus type 1. J. Gen. Virol. 1985, 66 (Pt 2), 231-247.

22. Telford, E.A.; Watson, M.S.; McBride, K.; Davison, A.J. The DNA sequence of equine herpesvirus-1. Virology 1992, 189, 304-316.

23. Telford, E.A.; Watson, M.S.; Perry, J.; Cullinane, A.A.; Davison, A.J. The DNA sequence of equine herpesvirus-4. J. Gen. Virol. 1998, 79, 1197-1203.

24. Patel, J.R.; Heldens, J. Equine herpesviruses 1 (EHV-1) and 4 (EHV-4)-Epidemiology, disease and immunoprophylaxis: A brief review. Vet. J. 2005, 170, 14-23. 
25. Osterrieder, N.; van de Walle, G.R. Pathogenic potential of equine alphaherpesviruses: The importance of the mononuclear cell compartment in disease outcome. Vet. Microbiol. 2010, 143, 21-28.

26. Azab, W.; Kato, K.; Abdel-Gawad, A.; Tohya, Y.; Akashi, H. Equine herpesvirus 4: Recent advances using BAC technology. Vet. Microbial. 2011, 150, 1-14.

27. Smith, K.C.; Whitwell, K.E.; Blunden, A.S.; Bestbier, M.E.; Scase, T.J.; Geraghty, R.J.; Nugent, J.; Davis-Poynter, N.J.; Cardwell, J.M. Equine herpesvirus-1 abortion: Atypical cases with lesions largely or wholly restricted to the placenta. Equine Vet. J. 2004, 36, 79-82.

28. Smith, K.C.; Borchers, K. A study of the pathogenesis of equid herpesvirus-1 (EHV-1) abortion by DNA in-situ hybridization. J. Comp. Pathol. 2001, 125, 304-310.

29. Gilkerson, J.R.; Love, D.N.; Whalley, J.M. Epidemiology of equine herpesvirus abortion: Searching for clues to the future. Aust. Vet. J. 1998, 76, 675-676.

30. Pusterla, N.; David Wilson, W.; Madigan, J.E.; Ferraro, G.L. Equine herpesvirus-1 myeloencephalopathy: A review of recent developments. Vet. J. 2009, 180, 279-289.

31. Borchers, K.; Thein, R.; Sterner-Kock, A. Pathogenesis of equine herpesvirus-associated neurological disease: A revised explanation. Equine Vet. J. 2006, 38, 283-287.

32. Azab, W.; Lehmann, M.J.; Osterrieder, N. Glycoprotein H and $\alpha 4 \beta 1$ Integrins Determine the Entry Pathway of Alphaherpesviruses. J. Virol. 2013, 87, 5937-5948.

33. Azab, W.; Osterrieder, N. Glycoproteins D of equine herpesvirus type 1 (EHV-1) and EHV-4 determine cellular tropism independently of integrins. J. Virol. 2012, 86, 2031-2044.

34. Azab, W.; Tsujimura, K.; Maeda, K.; Kobayashi, K.; Mohamed, Y.M.; Kato, K.; Matsumura, T.; Akashi, H. Glycoprotein $\mathrm{C}$ of equine herpesvirus 4 plays a role in viral binding to cell surface heparan sulfate. Virus Res. 2010, 151, 1-9.

35. Azab, W.; Zajic, L.; Osterrieder, N. The role of glycoprotein H of equine herpesviruses 1 and 4 (EHV-1 and EHV-4) in cellular host range and integrin binding. Vet. Res. 2012, 43, 61.

36. Graham, K.L.; Fleming, F.E.; Halasz, P.; Hewish, M.J.; Nagesha, H.S.; Holmes, I.H.; Takada, Y.; Coulson, B.S. Rotaviruses interact with $\alpha 4 \beta 7$ and $\alpha 4 \beta 1$ integrins by binding the same integrin domains as natural ligands. J. Gen. Virol. 2005, 86 (Pt 12), 3397-3408.

37. Crowhurst, F.A.; Dickinson, G.; Burrows, R. An outbreak of paresis in mares and geldings associated with equid herpesvirus 1. Vet. Rec. 1981, 109, 527-528.

38. Osterrieder, N.; Schumacher, D.; Trapp, S.; Beer, M.; von Einem, J.; Tischer, K. Establishment and use of infectious bacterial artificial chromosome (BAC) DNA clones of animal herpesviruses. Berl. und Munch. tierarztl. Wochenschr. 2003, 116, 373-380.

39. Von Einem, J.; Wellington, J.; Whalley, J.M.; Osterrieder, K.; O’Callaghan, D.J.; Osterrieder, N. The truncated form of glycoprotein gp2 of equine herpesvirus 1 (EHV-1) vaccine strain KyA is not functionally equivalent to full-length gp2 encoded by EHV-1 wild-type strain RacL11. J. Virol. 2004, 78, 3003-3013.

40. Goodman, L.B.; Loregian, A.; Perkins, G.A.; Nugent, J.; Buckles, E.L.; Mercorelli, B.; Kydd, J.H.; Palu, G.; Smith, K.C.; Osterrieder, N.; et al. A point mutation in a herpesvirus polymerase determines neuropathogenicity. PLoS Pathog. 2007, 3, e160. 
41. Azab, W.; Kato, K.; Arii, J.; Tsujimura, K.; Yamane, D.; Tohya, Y.; Matsumura, T.; Akashi, H. Cloning of the genome of equine herpesvirus 4 strain TH20p as an infectious bacterial artificial chromosome. Arch. Virol. 2009, 154, 833-842.

42. Azab, W.; Tsujimura, K.; Kato, K.; Arii, J.; Morimoto, T.; Kawaguchi, Y.; Tohya, Y.; Matsumura, T.; Akashi, H. Characterization of a thymidine kinase-deficient mutant of equine herpesvirus 4 and in vitro susceptibility of the virus to antiviral agents. Antivir. Res. 2010, 85, 389-395.

43. Rudolph, J.; O'Callaghan, D.J.; Osterrieder, N. Cloning of the genomes of equine herpesvirus type 1 (EHV-1) strains KyA and racL11 as bacterial artificial chromosomes (BAC). J. Vet. Med. B Infect. Dis. Vet. Public Health 2002, 49, 31-36.

44. Lee, E.C.; Yu, D.; Martinez de Velasco, J.; Tessarollo, L.; Swing, D.A.; Court, D.L.; Jenkins, N.A.; Copeland, N.G. A highly efficient Escherichia coli-based chromosome engineering system adapted for recombinogenic targeting and subcloning of BAC DNA. Genomics 2001, 73, 56-65.

45. Tischer, B.K.; von Einem, J.; Kaufer, B.; Osterrieder, N. Two-step red-mediated recombination for versatile high-efficiency markerless DNA manipulation in Escherichia coli. Biotechniques 2006, 40, 191-197.

46. Von Einem, J.; Smith, P.M.; Van de Walle, G.R.; O'Callaghan, D.J.; Osterrieder, N. In vitro and in vivo characterization of equine herpesvirus type 1 (EHV-1) mutants devoid of the viral chemokine-binding glycoprotein G (gG). Virology 2007, 362, 151-162.

47. Allen, G.P.; Yeargan, M.R. Use of lambda gt11 and monoclonal antibodies to map the genes for the six major glycoproteins of equine herpesvirus 1. J. Virol. 1987, 61, 2454-2461.

48. Sullivan, D.C.; Allen, G.P.; O'Callaghan, D.J. Synthesis and processing of equine herpesvirus type 1 glycoprotein 14. Virology 1989, 173, 638-646.

49. Whalley, J.M.; Ruitenberg, K.M.; Sullivan, K.; Seshadri, L.; Hansen, K.; Birch, D.; Gilkerson, J.R.; Wellington, J.E. Host cell tropism of equine herpesviruses: Glycoprotein D of EHV-1 enables EHV-4 to infect a non-permissive cell line. Arch. Virol. 2007, 152, 717-725.

50. Nabi, I.R.; Le, P.U. Caveolae/raft-dependent endocytosis. J. Cell Biol. 2003, 161, 673-677.

51. Macia, E.; Ehrlich, M.; Massol, R.; Boucrot, E.; Brunner, C.; Kirchhausen, T. Dynasore, a cell-permeable inhibitor of dynamin. Dev. Cell 2006, 10, 839-850.

52. Pelkmans, L.; Puntener, D.; Helenius, A. Local actin polymerization and dynamin recruitment in SV40-induced internalization of caveolae. Science 2002, 296, 535-539.

53. Wang, L.H.; Rothberg, K.G.; Anderson, R.G. Mis-assembly of clathrin lattices on endosomes reveals a regulatory switch for coated pit formation. J. Cell Biol. 1993, 123, 1107-1117.

54. Rauh, I.; Mettenleiter, T.C. Pseudorabies virus glycoproteins gII and gp50 are essential for virus penetration. J. Virol. 1991, 65, 5348-5356.

55. Rauh, I.; Weiland, F.; Fehler, F.; Keil, G.M.; Mettenleiter, T.C. Pseudorabies virus mutants lacking the essential glycoprotein gII can be complemented by glycoprotein gI of bovine herpesvirus 1 . J. Virol. 1991, 65, 621-631.

56. Kopp, A.; Blewett, E.; Misra, V.; Mettenleiter, T.C. Proteolytic cleavage of bovine herpesvirus 1 (BHV-1) glycoprotein $\mathrm{gB}$ is not necessary for its function in BHV-1 or pseudorabies virus. J. Virol. 1994, 68, 1667-1674. 
57. Packiarajah, P.; Walker, C.; Gilkerson, J.; Whalley, J.M.; Love, D.N. Immune responses and protective efficacy of recombinant baculovirus-expressed glycoproteins of equine herpesvirus 1 (EHV-1) gB, gC and $\mathrm{gD}$ alone or in combinations in BALB/c mice. Vet. Microbial. 1998, 61, 261-278.

58. Maresova, L.; Pasieka, T.J.; Homan, E.; Gerday, E.; Grose, C. Incorporation of three endocytosed varicella-zoster virus glycoproteins, $\mathrm{gE}, \mathrm{gH}$, and $\mathrm{gB}$, into the virion envelope. J. Virol. 2005, 79, 997-1007.

59. Farnsworth, A.; Wisner, T.W.; Webb, M.; Roller, R.; Cohen, G.; Eisenberg, R.; Johnson, D.C. Herpes simplex virus glycoproteins $\mathrm{gB}$ and $\mathrm{gH}$ function in fusion between the virion envelope and the outer nuclear membrane. Proc. Natl. Acad. Sci. USA 2007, 104, 10187-10192.

60. Krishnan, H.H.; Sharma-Walia, N.; Zeng, L.; Gao, S.J.; Chandran, B. Envelope glycoprotein gB of Kaposi's sarcoma-associated herpesvirus is essential for egress from infected cells. J. Virol. 2005, 79, 10952-10967.

61. Kopp, A.; Mettenleiter, T.C. Stable rescue of a glycoprotein gII deletion mutant of pseudorabies virus by glycoprotein gI of bovine herpesvirus 1. J. Virol. 1992, 66, 2754-2762.

62. Fan, Q.; Longnecker, R.; Connolly, S.A. Substitution of herpes simplex virus 1 entry glycoproteins with those of saimiriine herpesvirus 1 reveals a $\mathrm{gD}-\mathrm{gH} / \mathrm{gL}$ functional interaction and a region within the $\mathrm{gD}$ profusion domain that is critical for fusion. J. Virol. 2014, 88, 6470-6482.

63. Reed, S.M.; Toribio, R.E. Equine herpesvirus 1 and 4. Vet. Clin. N. Am. Equine Pract. 2004, 20, 631-642.

(C) 2015 by the authors; licensee MDPI, Basel, Switzerland. This article is an open access article distributed under the terms and conditions of the Creative Commons Attribution license (http://creativecommons.org/licenses/by/4.0/). 